\title{
Oxidation of Methanol using Carburized Molybdenum Catalyst
}

\author{
Shamsul Izhar ${ }^{*}, 1,2$ and Masatoshi Nagai ${ }^{1}$ \\ ${ }^{1}$ Graduate School of Bio-applications and Systems Engineering, Tokyo University of Agriculture and Technology, 2-24 \\ Nakamachi, Koganei, Tokyo 184-8588, Japan \\ ${ }^{2}$ Department of Chemical and Environmental Engineering, Faculty of Engineering, Universiti Putra Malaysia, UPM \\ Serdang 43400, Selangor, Malaysia
}

\begin{abstract}
Molybdenum catalysts carburized in $\mathrm{CH}_{4} / \mathrm{H}_{2}$ exhibited activity for methanol electrooxidation (MOR) in half cell measurements. Mo carburized at 773 and $873 \mathrm{~K}$ showed high electrooxidation of methanol compared to carburization at other temperatures. Catalyst characterization was carried out by XRD and TPC. The active carbide species responsible to facilitate the MOR was the Mo oxycarbide and $\beta-\mathrm{Mo}_{2} \mathrm{C}$ species.
\end{abstract}

Keywords: Molybdenum carbide, Methanol oxidation reaction.

\section{INTRODUCTION}

Fuel cells have been well thought-out as substitute power source for the near future. Amongst the fuel cells that are currently applied today is the direct methanol fuel cell (DMFC), which has gain attention for use in electronic applications. Since the DMFC is made of membrane electrode assemblies consisting of precious Pt-metal alloy electrocatalysts, the expenditure to manufacture and marketable fuel cells is high. Thus, the foremost challenges in fuel cell research are to lessen the cost of the electrocatalyst either by lowering the Pt loading or by developing a non-precious catalyst. Especially in the latter case, it is essential to note that methanol oxidation reaction (MOR) catalyst requires a material with high electronic conductivity and electrocatalytic activity (because of the high 6electron transfer), passive towards corrosion in acidic electrolytes, and tolerant towards poisoning from the intermediates formed during the reaction [1].

Since transition metal carbides have been stated to have Pt-like chemical reactivities and electronic properties [2], there have been many studies related to the development of transition metal carbides for use as hydrogen fuel cell electrocatalysts. Tungsten and molybdenum carbide have been shown to have some electrocatalytic activity towards the MOR [3] and hydrogen oxidation reaction [4]. The reason for their good activity is their ability to dissociate water then subsequently acts as a good oxygen donor, which according to Iwasita [5] is an important requirement in MOR. Zellner et al. [6] reported that methanol dissociates on the tungsten carbide (WC) film to produce the methoxy intermediate $\left(\mathrm{CH}_{3} \mathrm{O}\right)$, which is stable on the WC surface. Hwu et al. [7] also reported the possible role of molybdenum carbides as promoters for WC electrocatalysts in methanol fuel cell applications.

*Address correspondence to this author at the Department of Chemical and Environmental Engineering, Faculty of Engineering, Universiti Putra Malaysia, 43400 UPM Serdang, Selangor, Malaysia;

Tel: +60389464428; Fax: +60386567120; E-mail: shamizhar@upm.edu.my
Although carburized catalysts have found to be a catalyst for MOR, there has been only little study on the catalysts active sites. In this work, various carbide phase was defined by varying the of carburization temperature during the catalyst preparation, in order to study the activity Mo carbide during MOR. The activity for MOR was performed using a half-cell electrode. Characterization of the carburized catalysts was carried out using XRD and temperature programmed carburization apparatus equipped with a quadrupole mass spectrometer.

\section{MATERIALS AND METHODOLOGY}

\subsection{Preparation of Mo Carbide Catalyst}

Mo carbide was prepared by a similar method reported by Izhar et al. [8]. In brief, $\mathrm{MoO}_{3}$ (Kishida) oxidic precursors were mounted into a quartz bed micro reactor and heated to $773 \mathrm{~K}$ in air for 1 hour at a heating rate of $10 \mathrm{~K} / \mathrm{min}$. After the temperature dropped to $573 \mathrm{~K}$, the gas was changed to a continuously flowing stream of $20 \% \mathrm{CH}_{4} / \mathrm{H}_{2}$ mixture. The temperature was increased to $773,873,973$ or $1073 \mathrm{~K}$, preserved at its final temperature for $2 \mathrm{~h}$, at a ramping rate of $1 \mathrm{~K} / \mathrm{min}$. The reducing mixture was then cooled to room temperature and passivated under a stream of $1 \% \mathrm{O}_{2} / \mathrm{He}$ gas for $12 \mathrm{~h}$. Mo carbides dispersed on Ketjenblack (KB) was prepared by solving the catalysts in methanol with weight ratio of 30:70. The blend is then stirred until methanol is vaporized and dried in air at $393 \mathrm{~K}$ overnight. An ethanol based catalyst ink was prepared by adding ethanol to the catalyst. Then a water-based $5 \mathrm{wt} \%$ Nafion solution (Aldrich) is directly added to the catalyst/ethanol slurry. Nafion content is set to $35 \mathrm{wt} \%$ and stirred in an ultrasonic mixer.

\subsection{Activity Screening and Catalyst Characterization}

Half-cell measurement was carried out based on a previous method [8], using a ring-disc electrode in $1.0 \mathrm{M}$ $\mathrm{H}_{2} \mathrm{SO}_{4}$ as the working electrolyte at room temperature. Methanol solution concentration dissolved with the working electrolyte was $1.5 \mathrm{~mol} / \mathrm{L}$. The working electrode and 
reference electrode is a glassy carbon electrode with a working chamber of $3 \mathrm{~mm}$ diameter and a platinum wire, respectively. The reference electrode consists of an $\mathrm{Ag} / \mathrm{AgCl}$ electrode (Hokuto Denko, RE-1B). Nafion solution was used as the binder. Continuous argon bubbling was added to ensure good distribution of methanol in the electrolyte. Measurements were made using a stream of argon alone with the catalyst attached to the glassy carbon electrode. The working electrodes were tested for anodic electrocatalytic activity. The cyclic voltammetry of the bulk carburized based catalyst and the KB supported catalyst was measured at a scan speed of $100 \mathrm{mV} / \mathrm{s}$. The bulk properties of the catalysts were measured by XRD (RINT2000, Rigaku) using $\mathrm{Cu} \mathrm{K} \alpha$ ray $(30 \mathrm{kV}, 26 \mathrm{~mA})$. Temperature programmed carburization (TPC) was performed to obtain the desorbed products in the gas phase that was analyzed using a quadrupole mass spectrometer (Quastar 422, Balzers Co.) connected online. Methane $(\mathrm{m} / \mathrm{z}=15), \mathrm{CO}(\mathrm{m} / \mathrm{z}=28)$ and $\mathrm{H}_{2} \mathrm{O}(\mathrm{m} / \mathrm{z}=18)$ were qualitatively analyzed using the quadrupole mass spectrometer at a scan speed of 10 scan s${ }^{-1}$ during the TPC.

\section{RESULTS AND DISCUSSION}

\subsection{Activity Screening of Mo-C/KB in Half-Electrode Cell Electrode}

Fig. (1) illustrates the cyclic voltammetry of Mo carbide catalysts supported by KB. In the forward sweeps, a clear peek at $500 \mathrm{mV}$ ( $v s$ RHE) and $150 \mathrm{mV}$ (vs RHE) during the reverse sweep can be observed with the presence of fuel in the electrolyte. However a small peak at $200 \mathrm{mV}$ ( $v s$ RHE) during forwards sweeps was observed only for the Mo carburized at $873 \mathrm{~K}$. This could be due to the carbide active sites becoming free from $\mathrm{H}$ adsorption. At $500 \mathrm{mV}$ ( $v s$ RHE), dissociation of water occurred, which is the oxygen donor of the reaction, thus probably producing $\mathrm{CO}_{2}$.

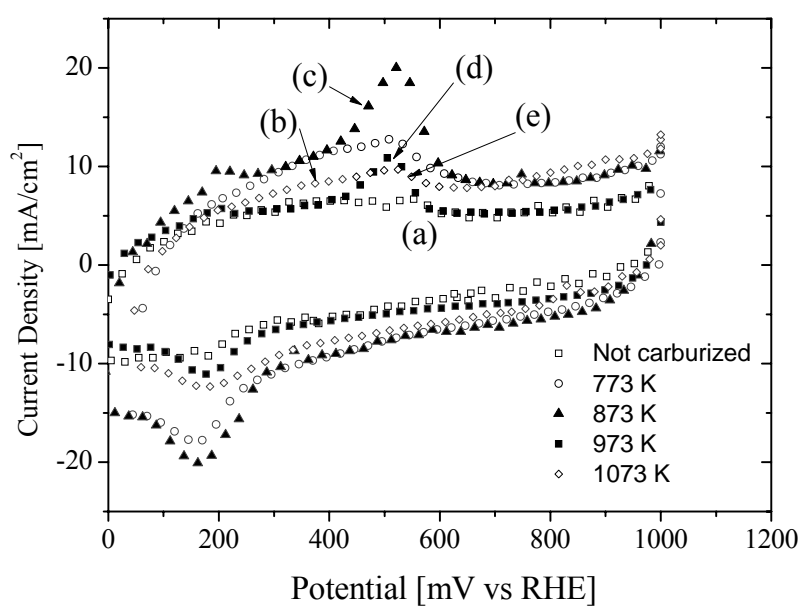

Fig. (1). Cyclic voltammetry of $30 \mathrm{wt} \%$ Mo oxide and carburized Mo catalysts supported by KB with $1.5 \mathrm{M}$ methanol solution in $1.0 \mathrm{~N}$ $\mathrm{H}_{2} \mathrm{SO}_{4}$ at room temperature. (a) non-carburized and catalysts carburized at (b) 773, (c) 873, (d) 973 and (e) $1073 \mathrm{~K}$.

Mo carburized at 773,873 and $973 \mathrm{~K}$ showed higher anodic activity with dissolved methanol compared to the activity in argon without fuel. At $500 \mathrm{mV}$ (vs RHE), all three showed highest current density between 10 and $20 \mathrm{~mA} / \mathrm{cm}^{2}$ respectively. However the $1073 \mathrm{~K}$-carburized catalyst showed current densities of $9 \mathrm{~mA} / \mathrm{cm}^{2}$, while the noncarburized $\mathrm{MoO}_{3} / \mathrm{KB}$ showed less than $1 \mathrm{~mA} / \mathrm{cm}^{2}$. The carburized Mo catalyst undoubtedly demonstrated better catalytic activity than the non-carburized $\mathrm{MoO}_{3} / \mathrm{KB}$.

The capacitive currents between 0.4 and $0.6 \mathrm{~V}$ ( $v s$ RHE) was determined by integration of the voltammogram in Fig. (1) between the $0.4-0.6 \mathrm{~V}$ ( $v s$ RHE) potential region. A commercial analysis program (OriginLab, Microcal Corp.) was used to determine the area using a non-linear peak fitting function. As shown in Fig. (2), the $873 \mathrm{~K}$-carburized Mo catalyst showed the highest capacitive current with 1310 $\mathrm{mC} / \mathrm{cm}^{2}$, followed by those carburized at $773\left(822 \mathrm{mC} / \mathrm{cm}^{2}\right)$ and $973 \mathrm{~K} \quad\left(518 \mathrm{mC} / \mathrm{cm}^{2}\right)$. This demonstrates that carburization temperature is an important factor in producing active carburized catalyst for methanol oxidation. This phenomenon is in agreement with a result by our group using cobalt molybdenum carbides for hydrogen oxidation reaction [9].

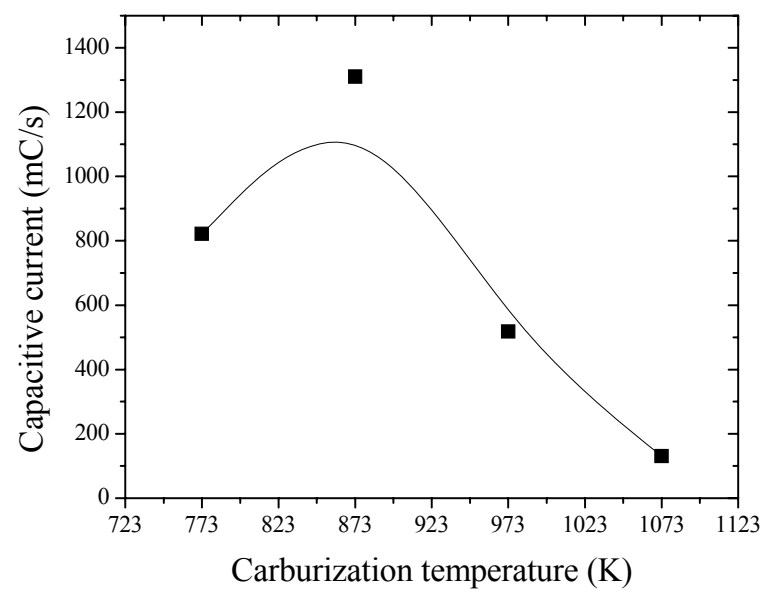

Fig. (2). Capacitive currents of the catalysts obtained by integration of voltammogram between 0.4 and $0.6 \mathrm{~V}$ ( $v s$ RHE) during cyclic voltammetry.

\subsection{XRD}

XRD measurement was performed over the carburized catalyst to give a wide view of the active species for MOR. The XRD analysis of the bulk Mo carburized at various temperatures are shown in the Fig. (3). The high intensity of $\beta-\mathrm{Mo}_{2} \mathrm{C}$ becomes clear as the carburization temperature increases to $973 \mathrm{~K}$. Small peaks at $2 \theta=12^{\circ}, 33^{\circ}, 38^{\circ}, 42^{\circ}$ and $62^{\circ}$ for the 773,873 and $973 \mathrm{~K}$ carburized Mo carbides were assigned to the oxycarbidic species according to Oshikawa et al. [10] and Oyama [11]. Broad peaks at $2 \theta=$ $25^{\circ}$ for all the supported catalyst is probably due to the presence of KB. For Mo carburized at $873 \mathrm{~K}$ that exhibited the highest activity, peaks of $\beta-\mathrm{Mo}_{2} \mathrm{C}$ and $\mathrm{MoO}_{\mathrm{x}} \mathrm{C}_{\mathrm{y}}$ were observed. This consequently illustrates the key to active species of Mo carbide for MOR was $\beta-\mathrm{Mo}_{2} \mathrm{C}$ and $\mathrm{MoO}_{\mathrm{x}} \mathrm{C}_{\mathrm{y}}$. This result is in agreement with Izhar et al. who revealed that oxycarbides are the active species for hydrogen oxidation reaction [9]. 


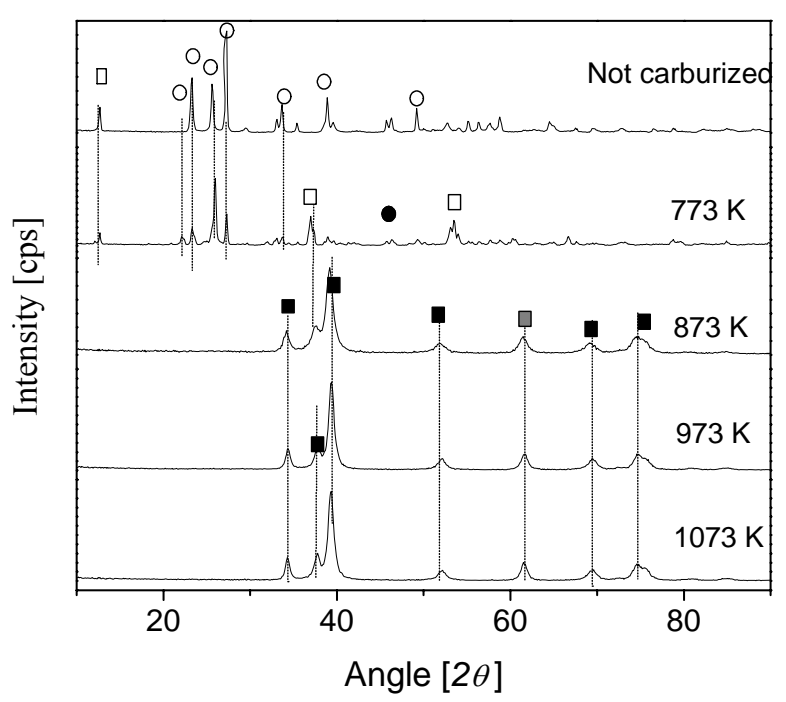

Fig. (3). XRD spectra of Mo carbides carbided at various temperatures. (O) $\mathrm{MoO}_{3},(\square) \mathrm{MoO}_{2},(\boldsymbol{\square}) \mathrm{MoO}_{\mathrm{x}} \mathrm{C}_{\mathrm{y}},(\boldsymbol{\bullet}) \beta-\mathrm{Mo}_{2} \mathrm{C}$.

\subsection{Temperature Programmed Carburization}

The evolution behavior of $\mathrm{H}_{2} \mathrm{O}$ and $\mathrm{CO}$ from the Mo carbide in the stream of $20 \% \mathrm{CH}_{4} / \mathrm{H}_{2}$ during the TPC is shown in Fig. (4). For the evolution of $\mathrm{H}_{2} \mathrm{O}$, a lowtemperature peak centered at 784 and a high-temperature peak at $948 \mathrm{~K}$ were observed. For the evolution of $\mathrm{CO}$, a small peak was observed at $967 \mathrm{~K}$. At $773 \mathrm{~K}$, the XRD result showed the presence of $\mathrm{MoO}_{3}$ and $\mathrm{MoO}_{2}$ were observed. Therefore, as the carburization temperature increased from 573 to $784 \mathrm{~K}$, the reduction of $\mathrm{MoO}_{3}$ to $\mathrm{MoO}_{2}$ took place. As the carburization temperature increased to $867 \mathrm{~K}$, the reduction of $\mathrm{MoO}_{3}$ to $\mathrm{MoO}_{2}$ and the reduction of $\mathrm{MoO}_{2}$ to the Mo oxycarbide $\left(\mathrm{MoO}_{\mathrm{x}} \mathrm{C}_{\mathrm{y}}\right)$ started. Finally, the remaining oxygen from the formation of water centered at $948 \mathrm{~K}$ is due to the transformation of the Mo oxycarbides and $\mathrm{MoO}_{2}$ to $\beta$ $\mathrm{Mo}_{2} \mathrm{C}$. This phenomenon verifies the XRD analysis in which the $873 \mathrm{~K}$ carburized MoC illustrated a clear difference in intensity compared to $923 \mathrm{~K}$ carburized MoC that exhibited

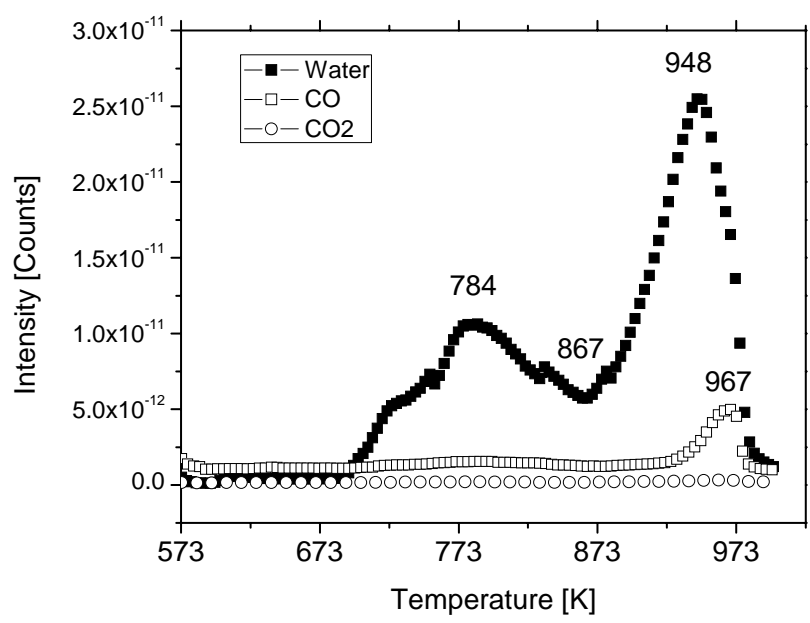

Fig. (4). Temperature programmed carburization of molybdenum from 573 to $1023 \mathrm{~K}$. the sharper peaks of $\beta-\mathrm{Mo}_{2} \mathrm{C}$ as shown in Fig. (3). The formation of $\mathrm{CO}$ at $967 \mathrm{~K}$ was related to the complete transformation of $\mathrm{MoO}_{2}$ to the $\beta-\mathrm{Mo}_{2} \mathrm{C}$ since XRD for 973 $\mathrm{K}$ carburized $\mathrm{MoC}$ showed peak intensity for the oxycarbide. Therefore, based on the TPC measurement, it can be concluded that the principle reactions taking place during the carburization are the reduction of $\mathrm{MoO}_{3}$ to $\beta-\mathrm{Mo}_{2} \mathrm{C}$ by $\mathrm{CH}_{4} / \mathrm{H}_{2}$, the deposition of carbon by the decomposition of methane, and the dissolution of carbon into the Mo system.

Since the activity towards the MOR is the highest for 873 $\mathrm{K}$ carburized MoC and the TPC showed the presence of $\mathrm{MoO}_{\mathrm{x}} \mathrm{C}_{\mathrm{y}}$ and $\beta-\mathrm{Mo}_{2} \mathrm{C}$ at $873 \mathrm{~K}$, the amount of oxygencontaining species (oxycarbide) in the catalyst is one of the factors to take into consideration as the active species. The oxycarbide species facilitated the reaction of the resulting residue with some $\mathrm{O}$-containing species to form $\mathrm{CO}_{2}$ (or $\mathrm{HCOOH})$. On the other hand, at above $973 \mathrm{~K}$, XRD demonstrated the presence of free carbon in the surface layer that resulted in a remarkable reduction of catalytic activity. Okamoto et al. [12] in their study on the role of oxygen in tungsten carbide has also shown that the MOR activity was significantly enhanced over tungsten carbide that included the most oxygen in the catalyst.

\section{CONCLUSION}

Molybdenum carbide catalysts prepared by carburization in a mixture of $20 \% \mathrm{CH}_{4} / \mathrm{H}_{2}$ at various temperatures was studied as catalysts for MOR. The carburized catalyst exhibited higher activity for methanol electrooxidation in half cell electrode measurements as compared to that without carburization. Furthermore, carburization of molybdenum at 773 and $873 \mathrm{~K}$ showed high electrooxidation of methanol compared to carburization at other temperatures. XRD and TPC were used to identify the active species for MOR. The active carbide responsible to facilitate the MOR was the Mo oxycarbide and $\beta-\mathrm{Mo}_{2} \mathrm{C}$ species.

\section{CONFLICT OF INTEREST}

The authors confirm that this article content has no conflict of interest.

\section{ACKNOWLEDGEMENTS}

Declared none.

\section{REFERENCES}

[1] Burstein, G.T.; Barnett, C.J.; Kucernak, A.R.; Williams, K.R. Aspects of the anodic oxidation of methanol. Catal. Today, 1997, $38,425-437$

[2] Oyama S.T. Preparation and catalytic properties of transition metal carbides and nitrides. Catal. Today, 1992, 15, 179-200.

[3] Bronoel, G.; Besse, S.; Tassin, N. Electrocatalytic methanol oxidation at PTFE-bonded electrodes for direct methanol-air fuel cell. Electrochim. Acta, 1992, 37, 1351-1353.

[4] Izhar, S.; Yoshida, M.; Nagai, M. Characterization and performances of cobalt-tungsten and molybdenum-tungsten carbides as anode catalyst for PEFC. Electrochim. Acta, 2009, 54, $1255-1262$

[5] Iwasita, T. T. Electrocatalysis of methanol oxidation. Electrochim. Acta, 2002, 47, 3663-3674.

[6] Zellner, M.B.; Chen, J.G. Surface science and electrochemical studies of WC and W2C PVD films as potential electrocatalysts. Catal. Today, 2005, 99, 299-307.

[7] Hwu, H.H.; Chen, J.G. Reactions of methanol and water over carbide-modified Mo(1 1 0). Surf. Sci., 2003, 536, 75-87. 
[8] Izhar, S.; Otsuka, S.; Nagai, M. Application of Carbon Supported NiMo Carburized Catalyst to Fuel Cell Anode Electrocatalyst. $J$. New Mater. Electrochem. Syst., 2008, 11, 15-20.

[9] Izhar, S.; Nagai, M. Cobalt molybdenum carbides as anode electrocatalyst for proton exchange membrane fuel cell. J. Power Sources, 2008, 182, 52-60.

[10] Oshikawa, K.; Nagai, M.; Omi, S. Characterization of Molybdenum Carbides for Methane Reforming by TPR, XRD, and XPS. J. Phys. Chem. B, 2001, 105, 9124-9131.
[11] Oyama, S.T. In: The Chemistry of Transition Metal Carbide and Nitrides; Oyama, S.T. Ed.; Chapman \& Hall, New York, 1996, p. 378.

[12] Nakazawa, M.; Okamoto, H. Surface composition of prepared tungsten carbide and its catalytic activity. Appl. Surf. Sci., 1985, 24, 75-86.

Received: February 28, 2013

Revised: August 23, 2013

Accepted: August 28, 2013

(C) Izhar and Nagai; Licensee Bentham Open .

This is an open access article licensed under the terms of the Creative Commons Attribution Non-Commercial License (http://creativecommons.org/licenses/by-nc/ 3.0/) which permits unrestricted, non-commercial use, distribution and reproduction in any medium, provided the work is properly cited. 